American Journal of Environmental Sciences 6 (4): 371-378, 2010

ISSN 1553-345X

(C) 2010 Science Publications

\title{
Co-Processing Trial of Spent Carbon at Wadi Cement Works Karnataka
}

\author{
${ }^{1}$ P. Singh Bundela, ${ }^{2}$ Momita Chakrawarty and ${ }^{3}$ S.P. Gautam \\ ${ }^{1}$ Regional Office, Madhya Pradesh Pollution Control Board Vijay Nagar, \\ Jabalpur, India 482002 \\ ${ }^{2}$ Associated Cement Corporation, Bombay, India \\ ${ }^{3}$ Central Pollution Control Board, New Delhi, India
}

\begin{abstract}
Problem statement: Co-processing in cement kiln perforce provides high temperature and long residence condition during the operation and is an effective technology for the management of waste in an environmentally friendly and safe manner. It fully absorbs the energy and material value of the waste without any harmful emissions. Approach: Co-processing in cement kiln ranks higher in the waste management hierarchy, when compared to other disposal options such as incineration and landfill. Unlike incineration and landfill, co-processing does not leave behind any residue that might have harmful impacts on the environment. Thus, co-processing is an ecologically sustainable solution for waste management. The co-processing trial run results concluded that the waste material, namely, Spent Carbon, can be safely co-processed in cement kilns. Results: The co-processing technology can provide a better, economically and ecologically more sustainable solution to industrial waste management problem. Conclusion/Recommendations: The trial burn of Spent Carbon waste has shown that it can be co-processed/disposed regularly in cement kiln without any adverse impact on process, quality and emissions.
\end{abstract}

Key words: Incineration, co-processing, landfill, cement kiln

\section{INTRODUCTION}

India is the second fastest growing major economy in the world, with a GDP growth rate of greater than $8 \%$. Due to the boom in the economy and enhanced industrial growth, the management of wastes generated, is posing a very serious threat to the society from the health, safety and environmental point of view. The generation rate of wastes in the country, as per the official records, is estimated to be about 8 million tons per annum and that of the Municipal Solid Waste (MSW) is about 40 million tons per annum (Chakrabarti, 2002). There are also numerous nonwastes from agricultural activities and industries, the generation rate of which is about 400 million tons per annum. Proper measures and guidelines are required for the management of these huge quantities of wastes, whether it be for their disposal or for their gainful utilization (Al-Hinti, 2006.). Co-processing refers to the use of waste materials in industrial processes as Alternative Fuels and Raw materials (AFR) to recover energy and material from them. Due to the high temperature and long residence time in cement kiln all types of wastes can be effectively disposed without any harmful emissions. Co-processing is a more environmentally friendly and sustainable method of waste disposal as compared to land filling and incineration because of reduced emissions and no residue after the treatment. The purpose of coprocessing trial is to demonstrate that the kiln is able to co-process waste in an environmentally safe and sound manner. The emission monitoring results of the trial burn forms a basis, to demonstrate that co-processing is an environmentally sound, effective waste disposal/recovery technology, to the authorities and other stakeholders associated with the activity. The coprocessing trial is carried out in three phases, namely, pre co-processing, co-processing and post coprocessing, in order to monitor the kiln stack emission before, during and after the co-processing of the waste material. All concerned stakeholders are informed about the trial in advance (Gautam et al., 2009a).

During the co-processing trial burn of Spent Carbon waste from Hindustan Coca Cola Beverages Private Limited (HCCBPL) conducted from 10-14th July, 2008 at ACC Wadi Cement Works, an experienced team comprising of senior officials from ACC were involved during the course of the co-

Corresponding Author: P.S. Bundela, Regional Office, Madhya Pradesh Pollution Control Board Vijay Nagar, Jabalpur, India 482002 Tel: +91-0761-4042780 Fax: +91-0761-4042780 
processing trial. Coca-Cola, the corporate nourishing the global community with the world's largest selling soft drink concentrates since 1886, returned to India in 1993 after a gap of 16 years giving a new thumbs up to the Indian Soft Drink Market. The vision of the company is to lead beverage revolution in the world and provide its consumer quality beverages at affordable price. Their operations in India-Hindustan Coca Cola Beverage Pvt. Ltd. (HCCBPL) comply with their global standards and are designed to least impact on the environment. HCCBPL is an ISO 9001 and ISO 14001 certified company (Gautam et al., 2009b).

Hindustan Coca Cola produces different kinds of wastes during its manufacturing operations located near Bangalore in the Karnataka state. These wastes are classified and treated as under the Waste (Management and Handling) Rules, 1989 as per the directive of the Karnataka State Pollution Control Board to $\mathrm{M} / \mathrm{s}$ Hindustan Coca Cola Beverage Pvt. Ltd. These wastes include: ETP Bio Solid, Water Treatment Plant Sludge and Spent Carbon (Barker et al., 2009).

Considering the benefits of co-processing, HCCBPL approached M/s. ACC Limited, for safe disposal of the wastes generated by their unit, through co-processing in ACC Wadi Cement Works, Gulburga. ACC conducted the prerequisite tests to evaluate the feasibility of co-processing of Spent Carbon at its Technical Support Services (TSS) in Thane and offered to co-process the same.

\section{MATERIALS AND METHODS}

Karnataka State Pollution Control Board (KSPCB) granted the necessary permission for co-processing in April 2007. Subsequently, ACC carried out detailed planning of the trial burn activity in association with HCCBPL and finalized the following: Standard Operating Procedure (SOP) and risk assessment procedure for spent carbon (Rasul et al., 2005). The coprocessing trial was carried out by ACC, under guidance of KSPCB, in presence of HCCBPL representatives, from 10-14th July, 2008. The trial was carried out in three phases, namely: Pre Co-processing, Co-processing and Post Co-processing

The monitoring of the emissions was carried out by SGS India Limited, Gurgaon. SGS is CPCB approved and ISO 17025 certified, third party monitoring agency. It has global experience in stack emission monitoring. They have carried out stack emission monitoring for the various co-processing trials conducted by $\mathrm{CPCB}$ and GTZ in the country as well. Before co-processing, the feed rate is estimated, for particular kilns, keeping in view the following practical impacts on the cement kiln:

- Impact on heat consumption

- Impact on kiln production rate

- Impact on power consumption

- Impact and conclusions on flame temperature

- Impact on clinker quality

The feed rate for Spent Carbon was calculated for Kiln 3 inlet of Wadi Cement Works. During the trial burn, calculated feed rate of 0.80 tons $\mathrm{h}^{-1}$ was maintained. At this feed rate 6300 tons of Spent Carbon can be disposed at Wadi kiln every year. Averagely the coal feed rate (average net calorific value of $4145 \mathrm{Kcal} \mathrm{Kg}^{-1}$ ) in the kiln 3 during the trial burn was 28.92 tons $\mathrm{h}^{-1}$. The Spent Carbon waste has the gross calorific value of $1710 \mathrm{Kcal} \mathrm{Kg}^{-1}$ which was used to evaporate the moisture content present. Hence, the Thermal Substitution Rate (TSR) is insignificant. Evaluation of the Spent Carbon Sample Received From M/s Hindustan Coca Cola Beverage Private Limited. The sample received was evaluated for the proximate analysis and calorific value. The analysis results of proximate sample was shown in Table 1.

The sample was converted into ash by firing it in a furnace at $85^{\circ}$ temperature for $3 \mathrm{~h} 730$ with natural air draft. The chemical analysis of the ashes was shown in Table 2.

Table 1: Analysis of proximate samples

\begin{tabular}{|c|c|c|c|c|c|c|}
\hline \multicolumn{7}{|c|}{ Proximate analysis } \\
\hline $\begin{array}{l}\text { Sample } \\
\text { details }\end{array}$ & $\begin{array}{l}\text { Moisture } \\
\text { (As recd.) }\end{array}$ & $\begin{array}{l}\text { VM (\%) } \\
\text { (ODB) }\end{array}$ & $\begin{array}{l}\mathrm{ASH}(\%) \\
(\mathrm{ODB})\end{array}$ & $\begin{array}{l}\text { Fixed (\%) } \\
\text { C (ODB) }\end{array}$ & $\begin{array}{l}\text { Calorific value } \\
\mathrm{Cal} / \mathrm{Gm}(\mathrm{GOD})\end{array}$ & $\mathrm{S}(\%)$ \\
\hline $\begin{array}{l}\text { Spent } \\
\text { carbon }\end{array}$ & 20.3 & 14.2 & 66.9 & 18.9 & 1710 & 0.04 \\
\hline
\end{tabular}

Table 2: Chemical composition of the ashes

\begin{tabular}{|c|c|}
\hline Components & Spent carbon ash \\
\hline$\overline{\mathrm{SiO}_{2}}$ & 82.50 \\
\hline $\mathrm{Al}_{2} \mathrm{O}_{3}$ & 3.00 \\
\hline $\mathrm{Fe}_{2} \mathrm{O}_{3}$ & 1.30 \\
\hline $\mathrm{CaO}$ & 0.60 \\
\hline $\mathrm{MgO}$ & 1.30 \\
\hline LOI(10000) & 0.70 \\
\hline $\mathrm{SO}_{3}$ & 0.60 \\
\hline Total.Cl' & 0.05 \\
\hline $\mathrm{Na}_{2} \mathrm{O}$ & 5.10 \\
\hline $\mathrm{K}_{2} \mathrm{O}$ & 2.04 \\
\hline $\mathrm{P}_{2} \mathrm{O}_{5}$ & 0.50 \\
\hline $\mathrm{TiO}_{2}$ & 0.20 \\
\hline $\mathrm{Mn}_{2} \mathrm{O}_{3}$ & 0.01 \\
\hline $\mathrm{ZnO}$ & -0.00 \\
\hline $\mathrm{BaO}$ & 0.10 \\
\hline $\mathrm{Cr}_{2} \mathrm{O}_{3}$ & -0.00 \\
\hline $\mathrm{PbO}$ & -0.00 \\
\hline
\end{tabular}


Dioxins and Furans, Total Organic Carbon (TOC), Poly Aromatic Hydrocarbon (PAH), Particulate Matter (Dust), $\mathrm{CO}_{2}, \mathrm{CO}, \mathrm{O}_{2}, \mathrm{NOx}, \mathrm{SO}_{2}, \mathrm{HCl}, \mathrm{HF}, \mathrm{HBr}, \mathrm{NH}_{3}$, $\mathrm{C}_{6} \mathrm{H}_{6}$ and Heavy Metal ( $\mathrm{Hg}, \mathrm{Sb}, \mathrm{As}, \mathrm{Cd}, \mathrm{Cr}, \mathrm{Co}, \mathrm{Cu}, \mathrm{Pb}$, $\mathrm{Mn}, \mathrm{Ni}, \mathrm{Tl}, \mathrm{V}$ ) emissions were monitored from both kiln stack during each phase of the co-processing trial. Proximate and ultimate analysis was conducted for Spent Carbon samples. The Spent Carbon samples were also tested for concentration of heavy metals, TOC, Total Petroleum Hydrocarbon, Organo Chlorine Compounds, Poly Chloro Biphenyls (PCBs), Poly Chloro Phenols (PCPs), Volatile Organic Compounds (VOC) and Semi VOCs. Representative samples of coal and raw meal were analyzed for heavy metals (Sb, As, $\mathrm{Cd}, \mathrm{Cr}, \mathrm{Co}, \mathrm{Cu}, \mathrm{Pb}, \mathrm{Mn}, \mathrm{Ni}, \mathrm{Tl}, \mathrm{V}$ ) and TOC during the entire trial period. Leachability test (including heavy metals i.e., $\mathrm{Cd}$, Th, $\mathrm{Hg}$, $\mathrm{Sb}, \mathrm{As}, \mathrm{Pb}, \mathrm{Cr}, \mathrm{Cu}, \mathrm{Mn}, \mathrm{V}, \mathrm{Zn}$, $\mathrm{Sn}, \mathrm{Se}$ ) was conducted for representative samples of clinker.

The following was concluded from the emission monitoring results during the co-processing trial: All the stack emission parameters were well within the CPCB norms for Common Waste Incinerators. Dioxin and furans levels were below $0.0035 \mathrm{ng}$ TEQ $\mathrm{Nm}^{-3}$ during each phase of the trial as against the norm of 0.1 ng TEQ $\mathrm{Nm}^{-3}$.
Plant, kiln and control system description: ACC Wadi Works was established in 1970 as a dry process plant with 2 kilns and a clinkerization capacity of 1200 tons per annum. Kiln 3 was commissioned in 1984. Currently, the plant has three kilns with a total capacity of 2.5 million tons per annum. The plant is located in the Gulburga district of Karnataka state. The major raw material components include limestone, clay, sandstone, blue dust and bauxite.

Cement production process in brief: Cement is made by heating a mixture of calcareous and argillaceous materials to a temperature of about $1450^{\circ} \mathrm{C}$. In this process, partial fusion occurs and nodules of clinker are formed. The cooled clinker is mixed with a few percent of gypsum and sometimes other cementations materials and ground into a fine meal-cement (Fig. 1).

The main components of clinker are lime $(\mathrm{CaO})$, silica $\left(\mathrm{SiO}_{2}\right)$, alumina $\left(\mathrm{Al}_{2} \mathrm{O}_{3}\right)$ and iron oxide $\left(\mathrm{Fe}_{2} \mathrm{O}_{3}\right)$. The first stage in the industrial process of cement manufacture is the quarrying of raw materials. To obtain the proper composition of the raw mix, corrective ingredients normally have to be added to the quarried raw materials. Examples of corrective materials are sand, bauxite and iron ore; which compensate for deficiencies of silica, alumina and iron oxide, respectively.

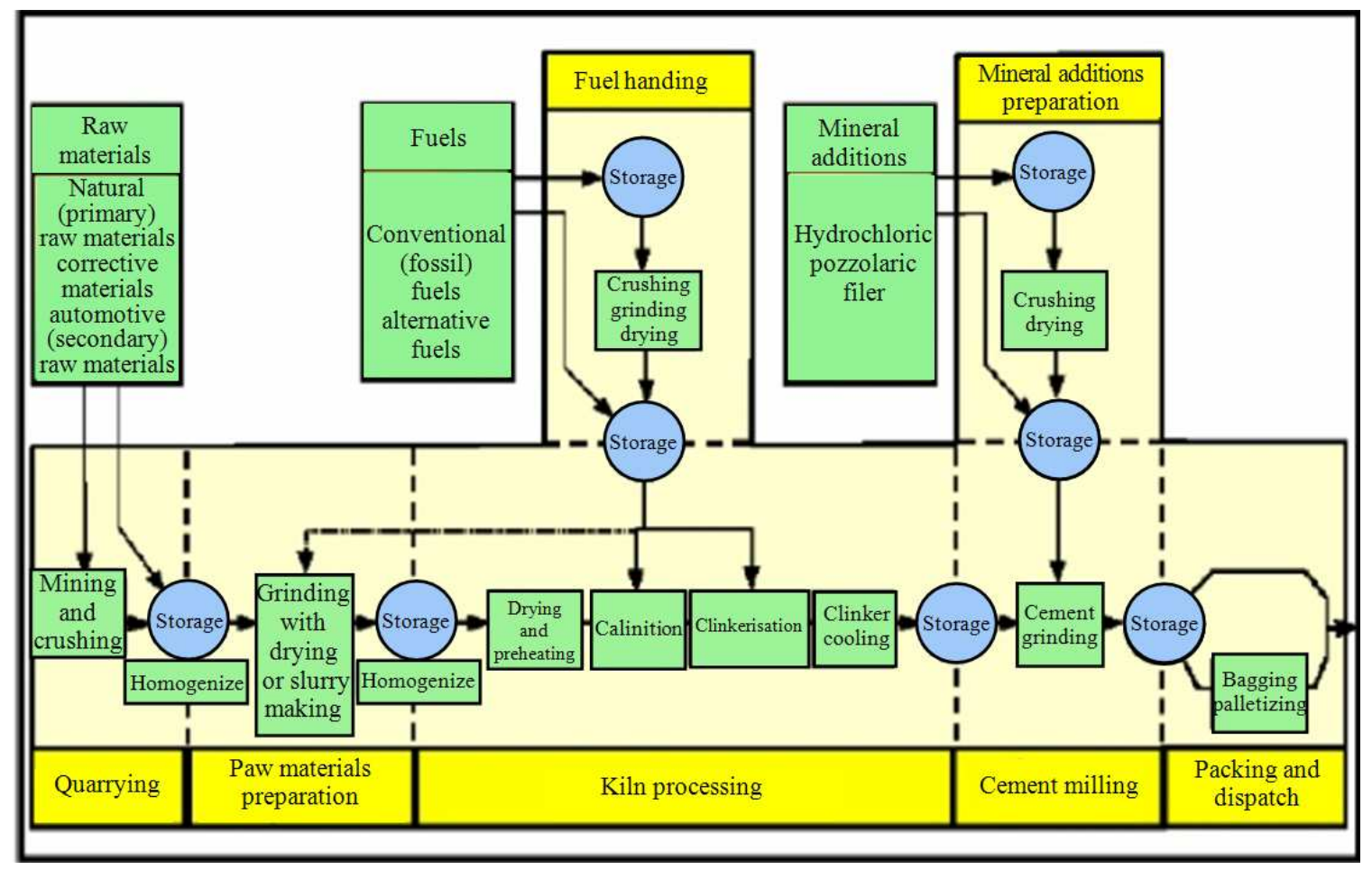

Fig. 1: Schematic diagram of cement production process 
After pre-blending, the chemically balanced raw mix passes through the mill feed system, to the 300 tons $\mathrm{h}^{-1}$ roller mill. The mill is fed with hot gases from the kiln to dry the raw mix to less than $1 \%$ humidity. The dried material is then conveyed to the blending silo where continuous homogenization ensures the correct raw meal composition. The clinker production is performed in a dry suspension pre-heater cement kiln equipped with a pre-calciner. The kiln rotates with a speed of 1.8 rounds per min, is 3.8 meter in diameter and $74 \mathrm{~m}$ long. It has a 5-stage pre-heater tower and produces approximately 3950 tones of the intermediate productclinker-per day. The clinker is cooled in a grate cooler, $40 \mathrm{~m}$ long and $3.3 \mathrm{~m}$ wide. The maximum feeding capacity is 270 tons of raw meal $\mathrm{h}^{-1}$ to the second stage cyclone from the top. The main burner is a Duflox, usually fired with 12 tons coal $\mathrm{h}^{-1}$. After the clinkerisation process the material is sent to the cement mill where the mineral component such as fly ash and gypsum are added to produce Portland Pozzolona cement.

Feeding arrangement for the waste material: The feeding system installed for the waste co-processing consists of hoist with bucket, hopper, belt conveyer, double flap damper and shut off gate. The hoist lifts the waste material packed in bags from the ground level to the 2 nd floor of the pre-heater tower. The capacity of the hoist is 3 tons. The volume of the hoist bucket is $0.75 \mathrm{~m}^{3}$. The material is unloaded from the bucket on the feeding platform. The waste packed in bags is then fed into the opening of feeding chute through a variable speed belt conveyor. A double flap damper is used in order to avoid the false air entry. A shut off gate has been incorporated in the system keeping safety considerations in view. Both the double flap damper and the shut off gate are interlocked with kiln operation ensuring safety in case of back firing. In order to maintain the feed rate of waste material, a counter is placed on the belt to check the number of bags coprocessed. A hooter has been provided at the platform which gives signal to the trained labor to put the waste packed in bag on to the belt at the pre-decided frequency according to the set point set from the central control room.

Waste used for trial: Coca Cola had returned to India in 1993 after a gap of 16 years giving a new thumb up to the Indian Soft Drink Market. M/s. Hindustan Coca Cola Beverages Private Limited (HCCBPL), located at outskirts of Bangalore. Their operations in IndiaHindustan Coca Cola Beverage Pvt. Ltd. (HCCBPL) comply with their global standards and are designed to least impact on the environment. HCCBPL is an ISO 9001 and ISO 14001 certified company. HCCBPL generates WTP sludge, Spent Carbon and ETP bio solid waste during its manufacturing operations was shown in Table 3. The following waste from HCCBPL was coprocessed during the trial burn conducted at ACC Wadi Cement Works from 10-14th July 2008.

The Spent Carbon waste is generated from the filtration process at HCCBPL. HCCBPL had forwarded the sample of the Spent Carbon waste to ACC for the evaluation of co-processing feasibility. The waste was analyzed at the RandD of ACC Limited located at Thane. Based on the analysis, ACC confirmed to HCCBPL that the Spent Carbon waste can be disposed by co-processing at cement kiln in ACC Wadi Works.

Receipt of spent carbon waste from HCCBPL for trial: Hindustan Coca cola beverages private limited delivered 64.28 tons of Spent Carbon waste for trial purpose. Total material was delivered in four trucks, bearing the following details:

Waste storage and handling:

Waste storage and handling at HCCB: The Spent Carbon was stored in HDPE bags (approx. weight $13.5 \mathrm{~kg}$ ) in Coca Cola's waste storage shed. The waste was transported to ACC Wadi Works in line with recommendation of CPCB on waste transportation was given in Table 4. The bags containing Spent Carbon were labeled and loaded manually on the truck.

Temporary waste storage shed at ACC wadi Works: The temporary waste storage shed at Wadi Works is covered, with concrete flooring and leach ate collection system. Boards displaying precautionary measures, safety signs and waste specific workplace labels for handling waste material are displayed at strategic locations. Fire extinguishers-both dry and $\mathrm{CO}_{2}$ type-are available in the storage shed. Risk Assessment Procedure (RAP) was prepared by ACC safety team in association with HCCBPL safety team for Spent Caron before transportation of waste from HCCBPL to Wadi Works.

Table 3: Type of waste

\begin{tabular}{lll}
\hline Type of waste & Category & Source of generation \\
\hline Spent carbon & 34.2 & Waste water treatment plant \\
\hline
\end{tabular}

Table 4: Transportation details of spent carbon

\begin{tabular}{lll}
\hline Truck number & Quantity (MT) & Received on \\
\hline KA 01 B 8960 & 16.06 & 6th June 08 \\
KA 01 B 8963 & 16.06 & 6th June 08 \\
KA 01 B 8959 & 16.09 & 8th June 08 \\
KA 01 B 8962 & 16.07 & 9th June 08 \\
\hline
\end{tabular}


Waste handling at ACC wadi cement works: The unloading operation was performed at ACC Wadi by four persons equipped with personal protective gear. These bags were unloaded manually and stored at designated sites in the storage shed. The workers and supervisors were trained in handling and safety aspects of waste well in advance of the trial burn. Concerned personnel were also trained on precautions to be undertaken, emergency measures, potential spill abatement, proper use and upkeep of PPEs, The bags were stacked in the containers under the supervision of AFR Coordinator. At the time of feeding the bags were loaded on tractor to transport the material from the storage shed to the hoist. Tarpaulin sheets were spread on the concrete floor of the storage shed and the bags were placed on the tarpaulin sheets to avoid any problems in case of leakage/spillage.

Storage of spent carbon near Kiln 3 during feeding: An area of $8 \times 5$ feet $^{2}$ at ground level near Kiln 3 was identified for temporary storage of the waste during feeding into kiln. The floor was covered with tarpaulin sheet and the area was barricaded.

Standard operating procedure for co-processing trial: Following are the standard operating procedure developed for the co-processing trial:

- The Truck containing the waste from HCCBPL, entered the premises of ACC Wadi Works through the weigh bridge, where the weight was recorded. The truck then moved towards the temporary storage area

- The concerned officer (AFR Coordinator) was informed by the security. The concerned officer checked the entire manifest related to transportation of waste

- Waste was unloaded from the truck with the help of laborers in presence of security guards, safety officer and kept at designated site in storage shed

- The weight of the material was recorded in the log book

- Empty truck was again weighed to check on the net weight of the material received

- The net weight of the truck was also recorded in the log book

- For co processing, the waste material packed in bags was loaded into the tractor trolley (dedicated for transporting the waste) with the help of labor and transported to the ground floor of the pre heater (near to the bucket of construction hoist) under the vigilance of guard and AFR coordinator

- Separate register was maintained for keeping the records of the material flow for the waste
- The waste material to be loaded into the bucket of the hoist so that it can be lifted to the 2nd floor where the waste feeding system to the kiln inlet is located

- The bucket to be emptied at the waste feeding platform by opening the gate at the bottom of the bucket

- The labor to put the bags on to the belt conveyer after receiving the signal from hooter (the frequency of which can be controlled from the central control room) and the bags to enter the kiln inlet through the chute

\section{RESULTS}

Outline of monitoring plan during co-processing trial: The purpose of the co-processing trial is to demonstrate that the kiln is able to co-process waste in an environmentally friendly manner. The emission monitoring results from the trial burn serves as a basis to demonstrate the environmentally sound performance of co-processing to the authorities and other stakeholders in the waste disposal activity. The coprocessing trial of Spent carbon waste from HCCBPL, which was conducted between 10-14th July, was carried out in three phases (namely, Pre Co-processing, Co-processing and Post Co-processing) and was as per the Holcim EMR Guidelines. There was a kiln stabilization period with conventional fuel for a span of $24 \mathrm{~h}$ before the start of the trial. Table 3 provides the list of emission parameters which were monitored during each phase of the trial. Hourly samples of all raw materials (lime stone, bauxite and iron ore), raw meal, kiln coal, calciner coal, clinker and Spent Carbon waste were collected and one composite sample on daily basis was made (Rasul et al., 2006.). The parameters that were analyzed in all the samples mentioned above were shown in Table 5-7.

Summary of co-processing trial schedule: The schedule for the co-processing trial of Spent Carbon waste from HCCBPL at ACC Wadi Cement works was as follows:

The co-processing trial burn was conducted in the presence of representatives from ACC and SGS. The team for trial burn was as mentioned below.

Table 5: Summary of co-processing trial schedule

Date

\begin{tabular}{lll}
\hline From & To & Phase \\
\hline 10th July 08 & 11th July 08 & Pre co-processing phase for spent carbon \\
12th July 08 & 13th July 08 & During co-processing phase with spent carbon \\
13th July 08 & 14th July 08 & Post co-processing phase for spent carbon \\
\hline
\end{tabular}


Process parameters during co-processing trial: During the pre co-processing, co-processing and post co-processing phase of the trial burn:

- $\quad$ The kiln feed rate, on an average, was 228, 234 and 237 tons $\mathrm{h}^{-1}$

- The coal feed rate to calciner, on an average, was 17.26, 17.59 and 18.44 tons $^{-1}$

- The coal feed rate to main burner of kiln, on an average, was $10.71,11.44$ and 11.33 tons $^{-1}$

Computer printouts of the hourly process chart of Kiln 3 there taken during the entire period of the coprocessing trial. The following parameters were monitored:

- $\quad$ Kiln Torque Kilo Watt (KW)

- $\quad$ Kiln Feed Rate Tons Per Hour (TPH)

- Coal Feed Rate to Kiln Tons Per Hour (TPH)

- Coal Feed Rate to Calciner Tons Per Hour (TPH)

- $\quad$ Last Cyclone Bottom Temperature $\left({ }^{\circ} \mathrm{C}\right)$ Stream 1

- $\quad$ Last Cyclone Bottom Temperature $\left({ }^{\circ} \mathrm{C}\right)$ Stream 2

- Kiln Speed Revolutions Per Minute (RPM)

- $\quad$ Pre Heater Outlet Temperature $\left({ }^{\circ} \mathrm{C}\right)$ Stream 1

- $\quad$ Pre Heater Outlet Temperature $\left({ }^{\circ} \mathrm{C}\right)$ Stream 2

- $\quad$ Pre Heater Draft (mm WC) String 1

- $\quad$ Pre Heater Draft (mm WC) String 2

- $\quad$ Pre Heater Outlet $\mathrm{O}_{2}(\%)$ String 1

- $\quad$ Pre Heater Outlet $\mathrm{O}_{2}(\%)$ String 2

- $\quad$ Pre Heater Outlet CO (\%) String 1

- $\quad$ Pre Heater Outlet CO (\%) String 2

- $\quad$ Kiln Inlet Temperature $\left({ }^{\circ} \mathrm{C}\right)$

Sampling conditions during co-processing trials: The sampling conditions and the stack parameters for Wadi Kiln 3 were estimated during the trial and are as shown in Table 6.

Results of emission monitoring during co-processing trial: The detailed results of the monitoring carried out during the co-processing trial are provided in the report submitted by SGS and is attached at the end of this report. The summary of the results are elaborated below. It is to be noted that the results are the average values for the number of samples collected at the time of emission monitoring during the trial.

Dioxins and furans: Sampling Procedure-USEPA Method No. 23 A-The monitoring results for each phase of the trial is summarized below.

Total organic compounds: Sampling ProcedureUSEPA Method No. 25 A-It is continuous online measurement for $24 \mathrm{~h}$. Flue gas is sampled via a heated probe and is passed through the hydrogen flame. The organic compounds gets ionization and the strength of ionization is reflected as ionization peaks in TOC analyzer screen and the peak area gives us the TOC content. The average emissions results during each phase of the trial burn are shown below.

Table 6: Sampling conditions and stack parameters during coprocessing trial

\begin{tabular}{llll}
\hline & & Average reading \\
Operation mode & Unit & Stream 1 & Stream 2 \\
\hline Stack diameter & $\mathrm{m}$ & 3.75 & \\
Cross section area & $\mathrm{m}^{2}$ & 11.05 & \\
Pressure & $\mathrm{mm} \mathrm{Hg}$ & 719 & \\
Gas temperature & ${ }^{\circ} \mathrm{C}$ & 141 & 138 \\
Moisture & volume \% & 18.5 & 19 \\
Oxygen content & volume \% & 9.6 & 9.8 \\
Carbon dioxide content & volume \% & 20 & 20.4 \\
Carbon monoxide & $\mathrm{mg} \mathrm{Nm}^{-3}$ & 162 & 190 \\
Exhaust gas velocity & $\mathrm{m}^{-\mathrm{s}}$ & 20.88 & 21.46 \\
Exhaust gas volume (stack conditions) & $\mathrm{m}^{3} \mathrm{~h}^{-1}$ & 830606 & 853679 \\
Exhaust gas volume (normal, wet) & $\mathrm{m}^{3}{ }_{\mathrm{n}, \mathrm{wet}} \mathrm{h}^{-1}$ & 565133 & 580831 \\
Exhaust gas volume (normal, dry) & $\mathrm{m}^{3}{ }_{\mathrm{n}, \mathrm{dry}} \mathrm{h}^{-1}$ & 460583 & 470473 \\
\hline
\end{tabular}

Table 7: Summary of co-processing trial results

Measured stack emission during the trial

\begin{tabular}{|c|c|c|c|c|c|c|c|}
\hline Parameter & Units & Norm & $\begin{array}{l}\text { Pre } \\
\text { co-processing }\end{array}$ & Co-processing & $\begin{array}{l}\text { Post } \\
\text { co-processing }\end{array}$ & $\begin{array}{l}\text { Change in emission } \\
\text { during co-processing } \\
\text { of the waste }\end{array}$ & $\begin{array}{l}\text { Change in emissions } \\
\text { after co-processing } \\
\text { the waste }\end{array}$ \\
\hline Dioxin and furan & $\mathrm{Ng} \mathrm{TEQ} / \mathrm{Nm}^{3}$ & 0.1 & 0.003 & 0.003 & 0.002 & - & 0 \\
\hline TOC & $\mathrm{mgC} \mathrm{Nm}^{-3}$ & 20 & 2.785 & 3.435 & 2.64 & 0.65 & -0.145 \\
\hline $\mathrm{HCl}$ & $\mathrm{mg} \mathrm{Nm}^{-3}$ & 4 & ND & ND & ND & ND & ND \\
\hline $\mathrm{HF}$ & $\mathrm{mg} \mathrm{Nm}^{-3}$ & 4 & ND & ND & ND & ND & ND \\
\hline $\mathrm{SO}_{2}$ & $\mathrm{mg} \mathrm{Nm}^{-3}$ & 200 & 11.94 & 17.82 & 27.14 & 5.878 & 15.193 \\
\hline PM & $\mathrm{mg} \mathrm{Nm}^{-3}$ & 50 & 213.1 & 153.02 & 107.51 & -60.082 & -105.592 \\
\hline $\mathrm{CO}$ & $\mathrm{mg} \mathrm{Nm}^{-3}$ & 100 & 289.18 & 534.63 & 885.46 & 245.45 & 596.275 \\
\hline NOx & $\mathrm{mg} \mathrm{Nm}^{-3}$ & 400 & 412.83 & 396.61 & 346.31 & -16.223 & -66.518 \\
\hline Mercury & $\mathrm{mg} \mathrm{Nm}^{-3}$ & 0.05 & 0.0015 & 0.0014 & 0.0008 & 0 & -0.001 \\
\hline $\begin{array}{l}\text { Heavy metals } \\
\text { (except Cd and } \mathrm{Tl})\end{array}$ & $\mathrm{mg} \mathrm{Nm}^{-3}$ & 0.5 & 0.0455 & 0.0136 & 0.0174 & -0.032 & -0.028 \\
\hline $\mathrm{Cd}$ and $\mathrm{Tl}$ & $\mathrm{mg} \mathrm{Nm}^{-3}$ & 0.05 & 0.0025 & 0.0014 & 0.0003 & -0.0011 & -0.002 \\
\hline
\end{tabular}

376


Hydrogen chloride and hydrogen fluorides: Sampling procedure-An integrated sample is extracted from the source and passed through a heated probe and filter into dilute sulfuric acid and dilute sodium hydroxide solutions which collect the gaseous hydrogen halides and halogens respectively. The filter collects particulate matter including halide salts but is not routinely recovered and analyzed. The hydrogen halides are soluble in the acidic solution and form chloride $\left(\mathrm{Cl}^{-}\right)$, bromide $\left(\mathrm{Br}^{-}\right)$and fluoride $\left(\mathrm{F}^{-}\right)$ions. The halogens have a very low solubility in the acidic solution and pass through to the alkaline solution where they are hydrolyzed to form a proton $\left(\mathrm{H}^{+}\right)$, the halide ion and the hypo halous acid ( $\mathrm{HClO}$ or $\mathrm{HBrO}$ ). Sodium this sulfate is added in excess to the alkaline solution to assure reaction with the hypo halous acid to form a second halide ion such that 2 halide ions are formed for each molecule of halogen gas. The halide ions in the separate solutions are measured by ion chromatography. Hydrogen chloride and hydrogen fluoride were monitored during all the three phases of the trial the monitoring results for each phase of the trial shown in Table 7.

\section{DISCUSSION}

Carbon monoxide, nitrogen and sulphur oxides and particulates: Sampling Procedure- $\mathrm{NO}_{\mathrm{X}}, \mathrm{O}_{2}, \mathrm{CO}_{2^{-}}$ Excess Air Fraction-USEPA Method No. 7 EInstrumental method using portable digital flue gas analyzer of Quintox make. Orsat Apparatus is used to determine the $\mathrm{O}_{2}$ and $\mathrm{CO}_{2}$. Flue gas is collected in the bladder and it is allowed to pass through $\mathrm{KOH}$ solution so that $\mathrm{CO}_{2}$ present in the flue gas gets absorbed. The flue gas is again passed through Pyrogalal solution so that $\mathrm{O}_{2}$ in the flue gas will get observed in it. $\mathrm{CO}$ is analyzed through flue gas analyzer as it cannot be determined by above method since the detection limit is $0.2 \%(1 \%=10,000 \mathrm{ppm}$, hence it is determined by flue gas analyzer). $\mathrm{SO}_{2}$-USEPA Method No. $6 \mathrm{~A} / \mathrm{B}$-A gas sample is extracted from a sampling point in the stack (Ba-Shammakh et al., 2008). The $\mathrm{SO}_{2}$ in the flue gas is absorbed in the $50 \mathrm{ml}$ of $6 \% \mathrm{H}_{2} \mathrm{O}_{2}$. The $\mathrm{SO}_{2}$ and the sulfur trioxide, including those fractions in any sulfur acid mist, are separated. The $\mathrm{SO}_{2}$ fraction is measured by the barium-thorium titration method. Particulate Matter-USEPA Method No. 17-Particulate matter is withdrawn iso-kinetically from the source and collected on a glass (Ghaly et al., 2007; Utlu et al., 2006). Fiber filter maintained at stack temperature. For these $1000 \mathrm{~L}$ of flue gas is collected and made it to pass through the thimble which weight is known to us after drying. After sampling the thimble is dried and weighed to find the \% of PM. The results were given in Table 7.
Metals:

Sampling procedure-hg and heavy metals-USEPA method N. 29: The measurements of the heavy metals namely Arsenic, Cadmium, Cobalt, Chromium, Copper, Mercury, Manganese, Nickel, Lead, Antimony, Tin, Thallium, Vanadium and Zinc are given in the Table 7. The results indicate that the emissions are within the given limits of the guidelines (Worell et al., 2000). A stack sample is withdrawn iso-kinetically from the source, particulate emissions are collected in the probe and on a heated filter and gaseous emissions are then collected in an aqueous acidic solution of hydrogen peroxide (analyzed for all metals including $\mathrm{Hg}$ ) and an aqueous acidic solution of potassium permanganate (analyzed only for $\mathrm{Hg}$ ). The recovered samples are digested and appropriate fractions are analyzed for $\mathrm{Hg}$ by Cold Vapor Atomic Absorption Spectroscopy (CVAAS) and for $\mathrm{Sb}, \mathrm{As}, \mathrm{Cd}, \mathrm{Cr}, \mathrm{Co}, \mathrm{Cu}, \mathrm{Pb}, \mathrm{Mn}, \mathrm{Ni}$, Tl, by Inductively Coupled Argon Plasma emission spectroscopy (ICAP) or Atomic Absorption Spectroscopy (AAS). Graphite Furnace Atomic Absorption Spectroscopy (GFAAS) is used for analysis of $\mathrm{Sb}, \mathrm{As}, \mathrm{Cd}, \mathrm{Co}, \mathrm{Pb}, \mathrm{Se}$ and $\mathrm{Tl}$ if these elements require greater analytical sensitivity than can be obtained by ICAP. If one so chooses, AAS may be used for analysis of all listed metals if the resulting in-stack method detection limits meet the goal of the testing program. Similarly, Inductively Coupled Plasma-Mass Spectroscopy (ICP-MS) can be used for analysis of Sb, As, $\mathrm{Cd}, \mathrm{Cr}, \mathrm{Co}, \mathrm{Cu}, \mathrm{Pb}, \mathrm{Mn}, \mathrm{Ni}$ and $\mathrm{Tl}$ (Yan et al., 2009).

\section{CONCLUSION}

The objective of this project was to perform a coprocessing trial to demonstrate that the cement kiln is able to co-process wastes in an irreversible and environmental sound manner, i.e., with no influence on the emissions when traditional fuel is partly replaced by waste. The waste, namely, Spent Carbon is generated by Hindustan Coca Cola Beverages Private Limited (HCCBPL), Bangalore. HCCBPL generates Spent Carbon from its filtration process and it is classified as as per HWM Rules. The co-processing trial was carried out together by ACC and HCCBPL from 10-14th July, 2008. The trial for Spent Carbon was carried out in three phases, namely, pre co-processing, co-processing and post co-processing. The emission monitoring was carried out by SGS Limited, Gurgaon. SGS is a CPCB approved, ISO 17025 certified, third party monitoring agency.

The monitoring results are summarized in below where the incremental variation in the emission during 
co-processing and post co-processing as compared with the baseline measurements are compared with the CPCB Norms for the Common Waste Incinerators. The CPCB guideline on Common Waste Incinerator provides emission standards for each parameter during incineration of waste. The graphs below compare these CPCB norms against the incremental variation of emissions during and after co-processing of the waste materials. The analysis results of the stack parameters revealed that the emission values are well below the standards set by CPCB for the Common Waste Incinerators. The test results concluded that the emissions were independent of the usage of the waste materials in the cement process. The cement process perforce requires high temperature in the kiln of around $1400-1450^{\circ} \mathrm{C}$ with a long residence time of $4-5 \mathrm{sec}$. Such high temperature conditions ensure that no noxious emissions take place during the co-processing of the waste materials. The advantages of high temperature cement kilns are widely utilized around the world and co-processing is regarded to e one of the most cost-effective and environment friendly and viable waste management technologies available.

\section{ACKNOWLEDGEMENT}

The researchers are thankful to ACC Wadi Cement works staffs for laboratory facilities and also thank to Karnataka pollution control board for his support.

\section{REFERENCES}

Al-Hinti, I.S., 2006. Energy saving potentials in Jordan through the introduction of diesel passenger cars. WSEAS Trans. Environ. Dev., 2: 479-501.

Ba-Shammakh, M., H. Caruso, A. Elkamel, E. Croiset and P.L. Douglas, 2008. Analysis and optimization of carbon dioxide emission mitigation options in the cement industry. Am. J. Environ. Sci., 4: 482-490. http://www.scipub.org/fulltext/ajes/ajes45482490.pdf

Barker, D.J., S.A. Turner, P.A. Napier-Moore, M. Clark and J.E. Davison, 2009. $\mathrm{CO}_{2}$ capture in the cement industry. Energy Procedia, 1: 87-94. DOI: 10.1016/j.egypro.2009.01.014
Chakrabarti, B.K., 2002. Investigation on heat loss through the kiln shell in magnesite dead burning process: A case study. Applied Therm. Eng., 22: 1339-1345. DOI: 10.1016/S13594311(02)00051-0

Ghaly, A.E., M.A. Kamal and R. Cote, 2007. Effect of temperature on the performance of limestone/sandstone filters treating landfill leachate. Am. J. Environ. Sci., 3: 11-18. http://www.scipub.org/fulltext/ajes/ajes311118.pdf

Gautam, S.P., P.S. Bundela and V. Chawla, 2009a. Coprocessing of plastic waste with coal in the cement kiln. J. Solid Waste Technol. Manage., 24: 1173-1179.

Gautam, S.P., R.K. Jain, B.N. Mohapatra, S.M. Joshi and R.M. Gupta, 2009b. Energy recovery from solid waste in cement rotary kiln and its environmental impact. J. Solid Waste Technol. Manage., 24: 1187-1198.

Rasul, M.G., W. Widianto and B. Mohanty, 2005. Assessment of the thermal performance and energy conservation opportunities of cement industry in Indonesia. Applied Therm. Eng., 25: 2950-2965. DOI: 10.1016/j.applthermaleng.2005.03.003

Rasul, M.G., I. Faisal and M.M.K. Khan, 2006. Environmental pollution generated from process industries in Bangladesh. J. Environ. Pollut., 28: 144-161. DOI: 10.1504/IJEP.2006.010881

Utlu, Z., Z. Sougt, A. Hepbasli and Z. Oktay, 2006. Energy and energy analyses of a raw mill in a cement production. Applied Therm. Eng., 26: 2479-2489. DOI: 10.1016/j.applthermaleng.2005.11.016

Worell, E., N. Marti and L. Price, 2000. Potential for energy efficiency improvement in the US cement industry. Energy, 25: 1189-1214. DOI: 10.1016/S0360-5442(00)00042-6

Yan, Q., C.B. Zhou, P. Qu and R. Zhang, 2009. The promotion of clean development mechanism to cement industry capturing waste heat for power generation in China. Mitigat. Adapt. Strat. Global Change, 14: 783-804. http://ideas.repec.org/a/spr/masfgc/v14y2009i8p79 3-804.html 